\title{
Negotiating for Release Time and Leave
}

\section{Maura Mast and Nathan Tintle}

\author{
Communicated by Christina Sormani
}

Editor's Note: We encourage readers to post their comments and suggestions at the Notices website, www. ams . org/notices.

Many large-scale research projects require a course release or a complete reduction in teaching responsibilities for a semester, a year, or more. This article suggests some ways to get them.

\section{Finding Funding}

There are three main sources of funding for course releases and leaves for research-active faculty: institutional or internal funding, external public funding (typically in the form of federal support from agencies such as the National Science Foundation, the National Security Agency, or the National Institutes of Health), and external private funding (typically from foundations or industry).

\section{Making the Case}

Many institutions view their internal research funding as "venture capital" or seed money; often this funding takes the form of a course release or summer salary. Early in the life of a new research project, securing institutional funding may be the best way to find a small amount of time and resources to get preliminary work done to position yourself for external funding. Making this case explicit to your internal funding officer is a good idea.

Regarding internally funded course releases, the best opportunity to negotiate for a course release with your institution is when you are hired. It's much easier for your chair to agree to a reduced teaching load for several semesters than to agree to a higher salary or credit toward tenure. Definitely ask for what you need regarding salary and credit toward promotion, but know that if the answer is no to those requests, the chair may be willing to give you a reduced load as a compromise. You can help with

Maura Mast is dean at Fordham College at Rose Hill. Her email address is mmast@fordham.edu.

Nathan Tintle is associate professor of statistics and director for research and scholarship, Dordt College. His email address is nathan.tint1e@dordt. edu.

For permission to reprint this article, please contact: reprint-permission@ams.org.

DOI: http://dx.doi.org/10.1090/noti1379

this request by making the case that your research likely has relatively low start-up costs compared to lab scientists. You should also be prepared to outline a specific project that you can reasonably accomplish given the course releases.

Both new and continuing faculty who ask for course reductions should be prepared to make an argument that it is worthwhile to get this exception. Don't assume that the institution will understand how important this time is for you. Instead, be clear about what you would achieve if you had the course release and be ready to update the chair during the semester. Be specific, concrete, and realistic. It's better to say, "I will use this time to build on work I've done on affine root systems to prepare a paper for submission to the Journal of Pure and Applied Algebra by the end of the semester" than "I need time to get started on some work I've been thinking about for a while." If you have achievements that resulted from these requests in the past, remind the chair of this ("Last fall I used my reduced teaching load to organize a grant-funded international conference. I've been invited to edit a volume based on talks at that meeting, and a course release this fall would allow me to focus on that responsibility.") You know your work best and you can help the chair make the case to

Be prepared to tell a good story about your work and why it's important. the dean by giving the chair some talking points to support your request. The administration will look for measurable outcomes-grants applied for, grants received, total funding amounts, papers submitted, talks given, conferences organized, etc.- - and you should couch your request with that in mind. When your paper does get accepted or when 
you do get the grant, notify the chair and the dean and thank them for their support.

Different offices in your institution may provide support in the form of a course release or summer salary for preparing grant or foundation applications. If you are part of a larger system, such as a state university system, you may be able to apply for a system-wide grant to support the development of a significant grant application or research project. Your sponsored-research office will likely view this type of program as a small expenditure with a large potential payback. Your international programs office may also provide small grants for international travel, either to a conference or for research work abroad. Even if these offices don't offer such support, talk to them about getting access to grant opportunities (such as a foundation database), help with grant writing, and offer ideas for making connections with other faculty with whom you could partner on proposals.

Like the sponsored-research office, the senior administrators at your institution may have seed money in the form of a course release or other activity to help faculty prepare a major grant proposal or start significant research work. Even if no such formal program exists, it's worth asking if the dean has discretionary funding to support your request. Be prepared to point to examples of how this has been successful, perhaps at your school's peer or aspirant peer institutions. And be prepared to tell a good story about your work and why it's important. The dean may be able to connect you to an external donor, such as an alum of your institution who shares your passion for this research and is willing to buy equipment or provide other support for it.

To be successful at obtaining external funding, you will need to do your research (find opportunities), learn how the system works (talk to grants officers, look at examples of successful proposals), and invest time in writing (and rewriting) a solid proposal that fits with the funding guidelines. While it may be initially more difficult to identify opportunities for funding from foundations or industry partners, it is worthwhile to look. Work with your institution's advancement/development office and your sponsored-research office early in this process.

\section{Other Keys to Success}

In this final section, we offer a few ideas for success in finding funding for your work.

\section{Shotgunning}

The funding landscape is much too fickle to let your entire research career and agenda ride on a single proposal. You must explore multiple funding options for each project. This likely will involve multiple different funding agencies and different spins on your core ideas. Just be careful that your proposal legitimately fits the request for proposals. Take the time to pitch your proposal carefully.

\section{Developing a Research Portfolio}

Just like any good investment portfolio, your research portfolio of projects should be well diversified. This includes projects that are mature and in a place where they are generating many important results, as well as new projects that may, some day, turn into a mature project.
You also need to be willing to eliminate the dogs from your portfolio-projects that, despite initial promise, are no longer worthy of your time.

\section{Momentum and Persistence}

Once you receive your first funding for a release or leave, you should certainly enjoy the moment. However, you must now doubly commit to completing the projects you proposed and writing additional proposals to build momentum in your research. This commitment also needs to be able to persist in the face of unfunded proposals, rejected papers, and the general roller-coaster ride of research.

\section{Learn to Be a Salesperson}

Obtaining support for your research requires learning about sales. The product is you and your research, and you are trying to get the funding agency to buy your product. Some people are better at sales than others. Don't be discouraged if you're uncomfortable with this. It may be helpful to go to a course or do some online reading about grant writing in order to learn about the art of sales from the perspective of grant writing. Agencies such as the National Science Foundation regularly give grant-writing presentations at the national meetings. If you can't attend one of these, contact the presenter to ask for a copy of the presentation. It's always a good idea to have someone who has been funded before read your proposal and give their sales critique before sending it off to the funding agency. Another key to being in sales is networking. This includes talking with your program officer as well as the other major players in your field of research. Identify strategic partners who are already successful in your research area and begin to cultivate collaborative relationships with them.

\section{Plan Ahead}

Too many researchers are not thinking more than a couple of steps ahead in their work. But in a highly competitive funding environment you need to be thinking three to five years ahead at a minimum. Federal funding agencies have turnaround times of at least six months, often with only one call for proposals for a specific program each year. Thus, being rejected twice before being successful could mean three years before your proposal is funded. While turnaround times at the institutional level tend to be shorter, it will still take time to get the relevant parties onboard and convinced. Take the time to plan ahead.

\section{Avoiding the Two Big Mistakes}

In our experience, there are two big mistakes that we've seen made by junior research faculty who are trying to get support to start their research. The first is that they feel entitled, which leads to an unwillingness to compromise or a feeling of frustration at being rejected for funding. It's important to learn to listen carefully to peer reviewers and funding agencies, learn from them, and make sure you keep your options for funding open. The second mistake is not getting started. It's true that writing a proposal is a lot of work. It's true that it's not fun to get turned down. It's also true that if you don't start, you'll never get funded and you risk losing the excitement, momentum, and passion that you currently have for your research. 
Small Funding Opportunities Shouldn't Be Overlooked

Look to different organizations for small funding. The Association for Women in Mathematics, for example, has regular competitions for travel grants and for mentoring grants. Applying for these grants will give you good practice in writing larger grant applications; success in obtaining these grants will help funding agencies and foundations see that you have a track record. Similarly, get on email distribution lists for grant opportunities, either from databases that your school subscribes to or from federal grant agencies. Don't forget private foundations and industry-sponsored opportunities!

\section{Accountability and Moral Support}

Consider forming a grant-writing group with other faculty, especially faculty from other disciplines. These networks can provide moral support and be a good resource for trying out ideas and proofreading proposals. These conversations may also lead to interdisciplinary projects.

\section{Get Started!}

Now that you've made it to the end of this article, it's time to get started. Create an action plan based on what you just read, including at least one specific to-do. Now go do it and enjoy the ride!

\section{About the Authors}

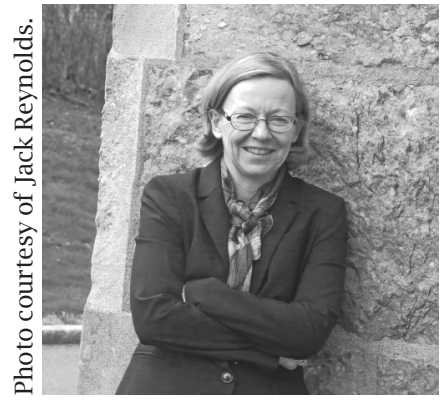

In the summer of 2015 , Maura Mast moved with her family from Boston to the Bronx to take the position of Dean of Fordham College at Rose Hill, part of Fordham University. She is the first woman-and the first mathematician-to serve as dean of the college.

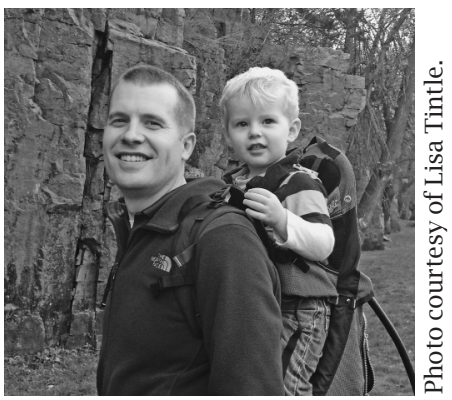

Nathan Tintle hiking in the Palisades of South Dakota with his two-yearold son, Mason.

\section{Twenty Years Ago in the Notices}

May 1996: A Personal Perspective on Mathematics Research in Industry, by Robert Calderbank.

Industrial labs where mathematics research is done have largely disappeared but still existed in 1996. His article gives insight into the rationale for having such labs.

www . ams . org/notices/199605/comm-calderbank.pdf 